\title{
Original Research \\ Effects of the Addition of Foils Produced from Polyethylene and Maize Starch to Composted Biomass on Quantitative and Qualitative Composition of Humic Compounds and Optic Parameters of Humic Acids
}

\author{
Krzysztof Gondek*, Monika Tabak, Małgorzata Koncewicz-Baran, Michał Kopeć \\ Department of Agricultural and Environmental Chemistry, University of Agriculture in Cracow, \\ A. Mickiewicza 21, 31-120 Cracow, Poland \\ Received: January 24, 2015 \\ Accepted: September 21, 2015
}

\begin{abstract}
We conducted this research in order to evaluate the effect of adding foils produced from polyethylene and maize starch on the quality of composts by means of a quantitative and qualitative analysis of humic compounds. Plant waste to which an $8 \%$ addition of foil was introduced (three foils with a different share of polyethylene and maize starch were examined) was the subject of the research. Five variants of compost were subjected to analysis: $\mathrm{C} 1$ - biomass without the addition of foil (control), $\mathrm{C} 2$ - biomass + foil 1, C3 - biomass + foil 2, C4 - biomass + foil 3 , and $\mathrm{C} 5$ - biomass + foil $3+$ microbiological inoculum. Composts that contained foil but not the inoculum were characterized by a higher total carbon content than the control compost; the addition of inoculum caused a decrease in total carbon content. The compost did not differ significantly in the humic acid carbon content, but a diversity in the fulvic acid carbon content was found. The ratio of humic acid to fulvic acid carbon content was most favorable in the (C2) compost. The addition of foil led to a slowdown of biomass humification. Composts with the addition of foil contained more non-hydrolyzing carbon than the control.
\end{abstract}

Keywords: compost, foil, humus compounds, humic acids, fulvic acids

\section{Introduction}

Dynamic growth of production and use of plastics, due to their durability and multifunctional purpose, is a result of their more and more common use in everyday life $[1,2]$. These materials are gradually replacing paper, glass, or wooden packaging. Increasing production of plastics used for various purposes generates considerable amounts of waste (in large countries, the annual plastic waste produc-

*e-mail: k.gondek@ur.krakow.pl tion reaches millions of tons), which is difficult to manage and poses a real hazard to the environment $[3,4]$. These materials are characterized by a considerable resistance to various factors (they do not naturally decompose to a large extent in the environment), which makes their organic recycling difficult $[4,5]$. An alternative for solving this problem may be to replace non-degradable plastics with a plant component $[6,7]$.

Decomposition of polymer materials with a plant component may occur as a result of the activity of enzymes produced by microorganisms [8-10]. Taking into account con- 
ditions under which the process of decomposition of such materials (aerobic or anaerobic) may occur, a product of this process may differ significantly in its physical and chemical properties, and also in kinds of dominating microflora that cause the changes. Composting is one method that may be commonly applied in the decomposition of materials of such a type [11-14]. Composting consists of biochemical transformations of these materials with the use of aerobic microorganisms at different temperature ranges. Three main phases may be distinguished in this process: mesophilic, thermophilic, and compost stabilization $[15,16]$. The final product of biomass decomposition in the composting process is a relatively stable fraction of organic matter (but water and carbon dioxide also are formed during the process) $[3,12,17]$.

Introduction of polyethylene-based polymers with the addition of a plant component to the composting process (which is conditioned by biological, chemical, and physical factors) may result in changes during the composting process, including changes in process dynamics. They can be caused by the chemical composition of a polymer, its molecular weight, supermolecular structure, physical and chemical properties, and also the ratio of the mass of material subjected to decomposition to its area [18-20].

Obtaining good quality compost offers a wide spectrum of its applications. The prerequisite for obtaining quality compost is selection of appropriate components (in terms of their physical and chemical properties) for the process. On one hand, the addition of polymers made of polyethylene and a plant component may be a hindrance to using the compost, because polyethylene does not undergo biological degradation and may pollute the obtained product, but on the other hand this material is enriched with a plant component and may improve the structure of the composted mass, positively contributing to the rate and trends of the process. Research was conducted on the quantitative and qualitative state of humic compounds in composts in order to assess the effect of the addition of foils produced from polyethylene and maize starch to composted biomass on the quality of obtained composts.

\section{Experimental Procedures}

\section{Biomass Preparation for Composting Process}

The research was conducted under laboratory conditions. The studied object was a mixture (hereafter referred to as biomass) prepared on the basis of plant waste: wheat straw (ws), rape straw (rs), and waste from pea seed cleaning (wpc). The mixture of the crushed and moistened components was prepared assuming a value of the $\mathrm{C}: \mathrm{N}$ ratio 30 as optimal for the conditions of the process. The abovementioned $\mathrm{C}: \mathrm{N}$ ratio was obtained at the following proportion of the components: $1(\mathrm{ws}): 1(\mathrm{rs}): 0.5(\mathrm{wpc})$. Selected parameters of the components used for biomass preparation are presented in Table 1. Moisture of the mixed biomass was $45 \%$ (that value was reached by using water). An $8 \%$ supplement (in relation to dry matter of the mixture) of
Table 1. Selected chemical parameters of materials used to prepare mixture of organic waste (mean $\pm \mathrm{SD}$ ).

\begin{tabular}{|l|c|c|c|c|}
\hline \multirow{2}{*}{ Material } & Dry matter & Ash & Total C & Total N \\
\cline { 2 - 5 } & $\begin{array}{c}\text { \% fresh } \\
\text { matter }\end{array}$ & \multicolumn{3}{|c|}{$\mathrm{g} \cdot \mathrm{kg}^{-1} \mathrm{~d} . \mathrm{m}}$. \\
\hline Wheat straw & $88.5 \pm 0.8$ & $38.4 \pm 0.2$ & $406 \pm 3.3$ & $5.3 \pm 0.2$ \\
\hline Rape straw & $88.2 \pm 1.0$ & $81.3 \pm 0.7$ & $374 \pm 2.4$ & $9.9 \pm 0.3$ \\
\hline $\begin{array}{l}\text { Waste from pea } \\
\text { seed cleaning }\end{array}$ & $90.1 \pm 1.3$ & $36.6 \pm 0.3$ & $369 \pm 1.2$ & $37.9 \pm 0.2$ \\
\hline
\end{tabular}

Table 2. Selected parameters of materials (foils) used in composting process.

\begin{tabular}{|c|c|c|c|}
\hline \multirow{2}{*}{ Film } & Polyethylene C & Maize starch & Compatibilizer \\
\cline { 2 - 4 } & \multicolumn{3}{|c|}{$\% \mathrm{w} / \mathrm{w}$} \\
\hline F(A) & 47.5 & 45.0 & 7.5 \\
\hline F(B) & 65.0 & 30.0 & 5.0 \\
\hline F(C) & 65.0 & 30.0 & 5.0 (with copolymer) \\
\hline
\end{tabular}

crushed foils made of polyethylene and maize starch was added to the prepared biomass. The foils were produced at the Central Mining Institute in Katowice, Poland. The materials used for the experiment differed in the share of polyethylene, maize starch, and compatibilizer (Table 2). The F(A) foil contained the highest share of maize starch and compatibilizer. The $F(B)$ and $F(C)$ foils differed in the copolymer addition (copolymer was added only to the $\mathrm{F}(\mathrm{C})$ foil).

\section{Conditions of Composting Process}

The experiment comprised the following variants conducted in two replications: $\mathrm{Cl}$ - biomass without foil (control), $\mathrm{C} 2$ - biomass + foil $1-\mathrm{F}(\mathrm{A}), \mathrm{C} 3$ - biomass + foil $2-$ $\mathrm{F}(\mathrm{B}), \mathrm{C} 4-$ biomass + foil $3-\mathrm{F}(\mathrm{C})$, and $\mathrm{C} 5-$ biomass + foil $3-\mathrm{F}(\mathrm{C})+$ microbiological inoculum (Neudorff Radivit $-\mathrm{a}$ universal preparation for composting). The composting process was conducted in $0.5 \mathrm{~m}$ high $\times 0.4 \mathrm{~m}$ long $\times 0.3 \mathrm{~m}$ wide bioreactors equipped with an aeration and sewage removal system. During the experiment, the biomass temperature was under control, maintained at $\sim 35-40^{\circ} \mathrm{C}$ until the $90^{\text {th }}$ day of the process and at $\sim 30^{\circ} \mathrm{C}$ to the $180^{\text {th }}$ day. The initial moisture content of the prepared mixtures was $60 \%$. During the process there was no need to refill water as the produced leachates were collected and returned. The biomass in the bioreactors was aerated in a $0.1 \mathrm{~m}^{3} \cdot \mathrm{min}^{-1}$ system, four times a day. To maintain optimal conditions of the process (better aeration and homogenization of the material), once a week the composted biomass was taken out of the bioreactors and mixed manually. Once the composting process was completed and the composts were mature, the materials were thoroughly mixed and samples were collected for chemical analyses. 
Table 3. Selected chemical parameters of composted biomass (mean $\pm \mathrm{SD}$ ).

\begin{tabular}{|c|c|c|c|c|}
\hline \multirow{2}{*}{ Compost } & Dry matter & Ash & Total C & Total $\mathrm{N}$ \\
\hline & $\%$ fresh matter & \multicolumn{3}{|c|}{$\mathrm{g} \cdot \mathrm{kg}^{-1} \mathrm{~d} . \mathrm{m}}$. \\
\hline (C1) Compost without foil & $23.4 \pm 3.9$ & $244 \pm 8.1$ & $374 \pm 0.3$ & $37.6 \pm 0.4$ \\
\hline (C2) Compost with F(A) & $20.5 \pm 4.0$ & $190 \pm 4.2$ & $445 \pm 4.8$ & $28.4 \pm 0.3$ \\
\hline (C3) Compost with F(B) & $18.2 \pm 4.1$ & $186 \pm 3.3$ & $462 \pm 3.0$ & $29.1 \pm 0.6$ \\
\hline (C4) Compost with F(C) & $24.6 \pm 4.1$ & $126 \pm 5.4$ & $555 \pm 1.1$ & $28.4 \pm 0.7$ \\
\hline (C5) Compost with $\mathrm{F}(\mathrm{C})$ and microbiological inoculum & $24.5 \pm 3.7$ & $204 \pm 1.0$ & $441 \pm 3.1$ & $34.5 \pm 0.7$ \\
\hline SD & 2.7 & 4.1 & 58.1 & 3.7 \\
\hline $\mathrm{V} \%$ & 6.1 & 21.0 & 12.8 & 11.9 \\
\hline
\end{tabular}

\section{Chemical Analyses in the Initial Material and in Composts}

The following were determined in the initial materials and in materials obtained after composting: dry matter content at $105^{\circ} \mathrm{C}$ for 12 hours; ash content after calcination in a chamber furnace at $500^{\circ} \mathrm{C}$ for eight hours; total nitrogen content assessed by distillation method following previous $\mathrm{N}-\mathrm{NO}_{3}$ reduction with Devarda's alloy and mineralization of the material sample in a concentrated sulphuric acid in an open system (under atmospheric pressure); and total carbon content $(\mathrm{Ct})$ by means of selective absorption in infrared on a Leco CNS 2000 analyzer.

Extraction of humic acids was conducted by the Schnitzer method [21], using a $0.5 \mathrm{~mol} \cdot \mathrm{dm}^{-3} \mathrm{NaOH}$ solution (Cex) (extraction for 24 hours). Carbon of humic acids (Cha) were separated from the extract by means of extract acidification with sulphuric acid to $\mathrm{pH} \sim 2$. In the second phase of the analysis carbon of hemicelluloses was separated from the composts after extraction with $\mathrm{H}_{2} \mathrm{SO}_{4}$ in concentration of $2.0 \mathrm{~mol} \cdot \mathrm{dm}^{-3}$ (extraction for 24 hours). Carbon content in the individual fractions was determined on the TOC-TN 1200 analyzer equipped with a non-dispersive infrared detector. Content of carbon of fulvic acids (Cfa) and non-hydrolyzing carbon $(\mathrm{Cnh})$ was calculated from the difference of, respectively:

$$
\begin{gathered}
\mathrm{Cfa}=\mathrm{Cex}-\mathrm{Cha} \\
\mathrm{Cnh}=\mathrm{Ct}-\mathrm{Cex}
\end{gathered}
$$

Optical properties within UV-VIS range were determined using a Beckman DU 640 spectrophotometer. To determine VIS spectra, $0.02 \%$ humic acid solutions in $0.1 \mathrm{~mol} \cdot \mathrm{dm}^{-3} \mathrm{NaOH}$ were prepared, and to determine UV spectra, samples were diluted in 1:5 ratio [22]. Based on the assessed values of absorbance at wavelengths of $280 \mathrm{~nm}$ $\left(\mathrm{A}_{2}\right), 465 \mathrm{~nm}\left(\mathrm{~A}_{4}\right), 665 \mathrm{~nm}\left(\mathrm{~A}_{6}\right)$, values of the following coefficients were computed:

$\mathrm{A}_{2 / 4}$ - ratio of absorbance values at wavelengths of 280 and $465 \mathrm{~nm}$

$\mathrm{A}_{2 / 6}$ - ratio of absorbance values at wavelengths of 280 and $665 \mathrm{~nm}$

$\mathrm{A}_{4 / 6}$ - ratio of absorbance values at wavelengths of 465 and $665 \mathrm{~nm}$

\section{Statistical Calculations}

The presented results of the analyses are an arithmetic mean for four replications. Standard deviation (SD) was computed for the arithmetic mean values presented in the tables, whereas the variation coefficient value $(\mathrm{V} \%)$ was computed to illustrate differences between individual composts. The value of correlation coefficient ( $r$ ) between selected parameters was also calculated.

\section{Results}

\section{Content of Dry Matter, Ash, Total Carbon, and Total Nitrogen in Composts}

(C2) and (C3) composts with the addition of foil made of polyethylene and maize starch contained lower amounts of dry matter in comparison with the control compost (C1) (Table 3). An increase in dry matter content in comparison with the value assessed in the control compost $(\mathrm{C} 1)$ was found in (C4) and (C5) composts, to which an $\mathrm{F}(\mathrm{C})$ polymer material, comprising 30\% thermoplastic starch, 65\% polyethylene $\mathrm{C}$, and 5\% compatibilizer, was added.

The ash content in the composts with the addition of foil was between $16 \%$ and $48 \%$ lower than the value assessed in the control compost (C1) (Table 3). Introduction of a microbiological inoculum to (C5) compost led to an increase in the ash content in comparison with the content assessed in (C4) compost, to which the same polymer material was introduced but without the microbiological inoculum.

The total carbon content in all composts with the addition of polymer materials was higher than the content assessed in the control compost (Table 3). The application of microbiological inoculum in the composting process led to an over $20 \%$ decrease in the total carbon content (when comparing the content in (C5) compost to the content in (C4) compost). An opposite dependence was registered in total nitrogen content (Table 3). The biggest quantity of this element was determined in the control compost $(\mathrm{C} 1)$ and in the compost with the addition of polymer material: $\mathrm{F}(\mathrm{C})$ and microbiological inoculum (C5). 
Table 4. Carbon content in the fractions of organic matter composted (mean $\pm \mathrm{SD}$ ).

\begin{tabular}{|c|c|c|c|c|c|c|}
\hline \multirow{4}{*}{ Compost } & \multicolumn{5}{|c|}{ C extracted } & \multirow{3}{*}{$\begin{array}{c}\text { C } \\
\text { non-hydrolyzing }\end{array}$} \\
\hline & \multicolumn{4}{|c|}{$0.5 \mathrm{~mol} \cdot \mathrm{dm}^{-3} \mathrm{NaOH}$} & \multirow{2}{*}{$\begin{array}{c}2.0 \mathrm{~mol} \cdot \mathrm{dm}^{-3} \\
\mathrm{H}_{2} \mathrm{SO}_{4}\end{array}$} & \\
\hline & C extract & $\mathrm{C}$ humic acids & C fulvic acids & \multirow{2}{*}{$\begin{array}{l}\mathrm{C} \text { humic acids: } \\
\mathrm{C} \text { fulvic acids ratio }\end{array}$} & & \\
\hline & \multicolumn{3}{|c|}{$\mathrm{g} \cdot \mathrm{kg}^{-1}$ d.m. } & & \multicolumn{2}{|c|}{$\mathrm{g} \cdot \mathrm{kg}^{-1}$ d.m. } \\
\hline (C1) Compost without foil & $114 \pm 1.1$ & $75.4 \pm 2.4$ & $38.7 \pm 0.4$ & $1.95 \pm 0.4$ & $29.6 \pm 1.4$ & $260 \pm 3$ \\
\hline (C2) Compost with F(A) & $122 \pm 2.2$ & $76.6 \pm 3.7$ & $45.4 \pm 2.5$ & $1.69 \pm 0.5$ & $24.7 \pm 0.4$ & $323 \pm 14$ \\
\hline (C3) Compost with F(B) & $120 \pm 3.7$ & $88.6 \pm 1.1$ & $31.8 \pm 1.1$ & $2.79 \pm 0.3$ & $21.4 \pm 0.3$ & $342 \pm 4$ \\
\hline (C4) Compost with F(C) & $125 \pm 5.9$ & $71.5 \pm 3.3$ & $53.9 \pm 2.0$ & $1.33 \pm 0.2$ & $18.2 \pm 1.5$ & $430 \pm 15$ \\
\hline $\begin{array}{l}\text { (C5) Compost with } \mathrm{F}(\mathrm{C}) \text { and } \\
\text { microbiological inoculum }\end{array}$ & $125 \pm 6.9$ & $80.2 \pm 1.7$ & $44.5 \pm 1.0$ & $1.81 \pm 0.2$ & $21.1 \pm 0.4$ & $316 \pm 5$ \\
\hline SD & 4.0 & 5.8 & 7.3 & 0.4 & 3.8 & 55.0 \\
\hline $\mathrm{V} \%$ & 3.3 & 7.3 & 16.9 & 25.4 & 17.1 & 16.4 \\
\hline
\end{tabular}

Table 5. Share of carbon of each fraction in total C content of organic matter composted.

\begin{tabular}{|c|c|c|c|c|c|}
\hline \multirow{4}{*}{ Compost } & \multicolumn{4}{|c|}{ C extracted } & \multirow{3}{*}{$\begin{array}{c}\text { C } \\
\text { non-hydrolyzing }\end{array}$} \\
\hline & \multicolumn{3}{|c|}{$0.5 \mathrm{~mol} \cdot \mathrm{dm}^{-3} \mathrm{NaOH}$} & \multirow{2}{*}{$\frac{2.0 \mathrm{~mol} \cdot \mathrm{dm}^{-3} \mathrm{H}_{2} \mathrm{SO}_{4}}{\mathrm{C} \text { hemicellulose }}$} & \\
\hline & $\mathrm{C}$ extract & $\mathrm{C}$ humic acids & $\mathrm{C}$ fulvic acids & & \\
\hline & \multicolumn{5}{|c|}{$\%$ Total C } \\
\hline (C1) Compost without foil & 30.5 & 20.2 & 10.3 & 7.9 & 69.5 \\
\hline (C2) Compost with F(A) & 27.4 & 17.2 & 10.2 & 5.5 & 72.6 \\
\hline (C3) Compost with F(B) & 26.1 & 19.2 & 6.9 & 4.6 & 73.8 \\
\hline (C4) Compost with F(C) & 22.6 & 12.9 & 9.7 & 3.2 & 77.3 \\
\hline $\begin{array}{l}\text { (C5) Compost with } \mathrm{F}(\mathrm{C}) \text { and } \\
\text { microbiological inoculum }\end{array}$ & 28.3 & 18.2 & 10.1 & 4.7 & 71.7 \\
\hline
\end{tabular}

The composting process led to a decrease in the $\mathrm{C}: \mathrm{N}$ ratio in the composts. Compared to the initial value, which was 30 , the $\mathrm{C}: \mathrm{N}$ ratio decreased to values within a range between 9 and 19 in the final stage of the process.

\section{Carbon Content in Humic Fractions of Mature Composts}

The content of humic compounds extracted with $\mathrm{NaOH}$ in $0.5 \mathrm{~mol} \cdot \mathrm{dm}^{-3}$ concentration revealed a small diversity between the composts ( $\mathrm{V} \% 3.3$ ) (Table 4); most of the carbon was extracted from (C4) and (C5) composts (125 $\mathrm{gC} \cdot \mathrm{kg}^{-1}$ d.m.). Bigger differences were demonstrated for the share of carbon extracted in this way in the total carbon content (Table 5). That share was between $23 \%$ and $31 \%$ and the highest was in the control compost.

The content of humic acid carbon was the highest in (C3) and (C5) composts (reaching $88.6 \mathrm{~g}$ and $80.2 \mathrm{gC} \cdot \mathrm{kg}^{-1}$ d.m., respectively) (Table 4). Among the composts that contained foils, those were the composts in which the share of humic acid carbon in the total carbon content (Table 5) was the highest, and at the same time the closest to the one found in the control compost $(\mathrm{C} 1)$.

An addition of biodegradable materials to the composted biomass led to a diversification in the Cha:Cfa ratio. Values of Cha:Cfa closest to the optimum (1.6) were obtained in compost (C2). In other composts values of the discussed parameter differed from 1.6, which is considered by some authors [23] to be the optimum for mature composts. The value of the Cha:Cfa ratio was significantly correlated with the content of humic acid carbon $(\mathrm{r}=0.935, \mathrm{p}<0.05)$ and with the content of fulvic acid carbon $(\mathrm{r}=-0.956, \mathrm{p}<0.05)$.

The content of hemicellulose carbon in the composts with the addition of foil was on a lower level than found in the control compost (C1) (Table 4). The share of hemicellulose carbon in the total carbon content was diversified, ranging from $3.2 \%$ to $7.9 \%$ (Table 5 ). As in the case of the 
Table 6. Optical properties of humic acids of composted organic matter (mean \pm SD).

\begin{tabular}{|l|c|c|c|}
\hline \multicolumn{1}{|c|}{ Compost } & $\mathrm{A}_{2 / 4}$ & $\mathrm{~A}_{2 / 6}$ & $\mathrm{~A}_{4 / 6}$ \\
\hline (C1) Compost without foil & $3.85 \pm 0.09$ & $28.9 \pm 0.10$ & $7.49 \pm 0.18$ \\
\hline (C2) Compost with F(A) & $4.03 \pm 0.08$ & $34.8 \pm 1.20$ & $8.61 \pm 2.89$ \\
\hline (C3) Compost with F(B) & $3.23 \pm 0.32$ & $30.4 \pm 1.20$ & $9.27 \pm 2.87$ \\
\hline (C4) Compost with F(C) & $5.10 \pm 0.80$ & $43.2 \pm 1.00$ & $8.43 \pm 0.71$ \\
\hline $\begin{array}{l}\text { (C5) Compost with F(C) } \\
\text { and microbiological } \\
\text { inoculum }\end{array}$ & $3.22 \pm 0.21$ & $32.0 \pm 2.10$ & $9.94 \pm 0.10$ \\
\hline SD & 0.7 & 5.6 & 0.9 \\
\hline V\% & 19.8 & 16.8 & 10.5 \\
\hline
\end{tabular}

$\mathrm{A}_{2 / 4}$ - absorbance value ratio at wavelengths of 280 and $465 \mathrm{~nm}$, $\mathrm{A}_{2 / 6}$ - absorbance value ratio at wavelengths of 280 and $665 \mathrm{~nm}$, $\mathrm{A}_{4 / 6}-$ absorbance value ratio at wavelengths of 465 and $665 \mathrm{~nm}$

absolute content of hemicellulose carbon, also the highest share of this form of carbon in the total carbon content was found in the control compost $(\mathrm{C} 1)$.

The content of non-hydrolyzing carbon in the composts with the addition of polymer materials fell within the range from 316 to $430 \mathrm{~g} \cdot \mathrm{kg}^{-1} \mathrm{~d} . \mathrm{m}$. and was higher than the content assessed in the control compost (C1) (Table 4). The share of non-hydrolyzing carbon in the total carbon content exceeded $70 \%$ only in the composts where a polymer material was added, whereas in the control compost it was lower (Table 5).

\section{Optical Properties of Humic Acids of Composted Organic Matter}

The calculated absorbance coefficients of humic acid solutions revealed changes depending on polymer material added to the composting process (Table 6). The smallest diversity was stated for $\mathrm{A}_{4 / 6}(\mathrm{~V} \%$ 10.5), and the highest for $A_{2 / 4}\left(V \%\right.$ 19.8). The values of $A_{2 / 6}$ and $A_{4 / 6}$ for the control compost reached 28.9 and 7.49 , and for the other composts they were higher and reached from 30.4 to 43.2 and from 8.43 to 9.94 , respectively. The value of $\mathrm{A}_{2 / 4}$ for the control compost (3.85) was higher than for (C3) and (C5) composts and lower than for the two other composts.

\section{Discussion of Results}

The common application of polymer materials results from their specific properties, which in some situations allow us to replace traditional materials such as glass, metal, or wood [24]. Introducing a biodegradable component to a traditional polymer decreases its durability, but improves the possibility to conduct degradation of these materials after use. Composting is one of the environmentally friendly methods used on a large scale in waste processing. In comparison with traditional recycling of poly- mer materials, the use of microorganisms or in fact their enzymes in the degradation process clearly diminishes the costs of transformation of these materials.

Biological transformation of polymer materials with the use of a biocomponent may involve difficulties with their proper preparation for the process (crushing) and with forming intermediate substances revealing an unfavorable effect limiting enzymatic activity of microorganisms $[25,26]$. This is connected with the quantitative addition of polymer materials to the composted biomass. Polymers modified with organic materials can constitute pollution in composting. Another problem that needs to be solved is selection of appropriate substratum, i.e. biomass, which should be used to ensure proper conditions for microorganisms. As demonstrated in the research by Pan and Sen [27], the effectiveness of a composting process is, among other things, conditioned by chemical composition of biomass subjected to biological transformation, which in turn conditions the metabolic activity of microorganisms. In the presented research a mixture of plant waste materials (wheat straw, rape straw, and waste generated during pea seed cleaning) was the substratum for the biological transformation of the polymer materials. The mixture was prepared based on the C:N value (in order to obtain $~ 30$ ), so that the process could take place under optimal conditions (which would ensure enough nitrogen for microorganisms that decompose carbon compounds). The prepared mixture of plant materials was a good source of carbon available to microorganisms. According to Raj and Antil [28], waste from the agri-food industry constitutes a valuable source of biomass for composting. The problem may be limited availability of one of the key components in terms of composting, i.e. nitrogen. It may significantly limit the enzymatic activity of the microorganisms, which leads to slowing down metabolic processes. As Gondek and Kopeć [29] demonstrated in their research, supplying to the composted biomass a source of carbon and nitrogen that would be readily available to microorganisms may significantly modify the rate of this process. Optimization of biomass composition (particularly when biomass is a substratum for disintegration of polymer materials) based only on the total $\mathrm{C}$ and $\mathrm{N}$ contents may be an inadequate criterion and lead to a necessity to correct biomass composition during the process. While studying the transformations of carbon and nitrogen compounds in composted animal fertilizers and in comminuted paper, Pare et al. [30] found out that the $\mathrm{C}: \mathrm{N}$ ratio, which is often used in the assessment of organic matter biodegradation and preparation of biomass for composting, should be based on the content of bioavailable forms. Also in the case of polymer material degradation, the kind and amount of added biocomponent are important elements of this process. According to Iovino et al. [10], biocomponents added to polymer materials are characterized by different susceptibility to biodegradation. According to the cited authors, thermoplastic starch (from coconut) is the material most susceptible to biodegradation.

In the presented research, thermoplastic maize starch in various additions was the biocomponent used for prepara- 
tion of foil. Information given in the work by $\mathrm{Gu}$ [31] indicates that polymer material degradation is a function of its structure, the population of microorganisms that decomposes the material, and conditions under which the process is conducted (which determine the number and activities of the microorganism population). On the other hand, Mohan and Srivastava [24] state that microorganism degradation effect on a polymer is a result of two processes:

i) direct effect, in which microorganisms worsen the properties of a polymer material treated as a source of components for their growth

ii) indirect effect, involving the impact of products of metabolic transformation of microorganisms, which in consequence leads to further worsening of polymer properties.

The addition of a polymer material has no clear impact on the quality of composts, which is mainly due to the specificity of the process and type of materials used for composting. By definition, adding a polymer material to composting should improve the conditions of the process, which should be reflected in the quantitative and qualitative composition of compost organic matter.

One of the indicators of composted organic matter quality is the value of the Cha:Cfa ratio. According to Iglesias Jiménez and Pérez Garcia [23], 1.6 is the optimal value for the Cha:Cfa ratio (data for the compost from municipal waste and sewage sludge). On the other hand, Inbar et al. [32] stated that the optimal value for this ratio is 1.5 . There is a relatively minor difference between the mentioned values of the Cha:Cfa ratio. Values of the Cha:Cfa ratio closest to 1.5-1.6 were obtained in (C2) and (C4) composts, to which foils containing respectively $45 \%$ and $30 \%$ of thermoplastic maize starch were added. Values of the discussed parameter in the other composts point to a much too advanced biomass mineralization process. However, it should be emphasized that in all the composts the content of humic acid carbon was higher than contents of fulvic acid carbon. In their research, Gusiatin and Kulikowska [33] also indicated an increase in the content of humic acid carbon, but a decrease in the content of fulvic acid carbon. Absorbance value of humic acids measured at $280 \mathrm{~nm}$ is determined by lignin content in acids, at $465 \mathrm{~nm}$ by content of substances at the initial stage of decomposition, and at $665 \mathrm{~nm}$ by content of substances with a high degree of humification [34, 35]. The greater the humification and molecular weight of humic acids, the lower the values of $\mathrm{A}_{2 / 4}, \mathrm{~A}_{2 / 6}$, and $\mathrm{A}_{4 / 6}$ absorbance ratios. Higher values of the $\mathrm{A}_{2 / 4}$ and $\mathrm{A}_{4 / 6}$ absorbance ratios concerning all composts to which foils were introduced (C2-C5) may be indicative of a decline in the degree of condensation of humic acid particles or greater aliphatization and greater number of functional groups [36].

In the early stages of formation, humic acids, usually with a smaller molecular mass and lower degree of condensation of aromatic structures, are characterized by higher values of the $\mathrm{A}_{4 / 6}$ ratio. Optical properties of humic acids may change not only under the influence of humification and mineralization of composted biomass, but also due to the kind of organic matter used in the composting process, including the amount and type of added polymer material. Composition and size of the population of microorganisms also plays a role. When foil marked with $\mathrm{F}(\mathrm{C})$ symbol was added (C4 and $\mathrm{C} 5$ composts), clear differences concerning the values of $A_{2 / 4}$ and $A_{2 / 6}$ were registered. For those two objects, the addition of microbiological inoculum intensified the humification process (it was shown as a decrease in $\mathrm{A}_{2 / 4}$ and $\mathrm{A}_{2 / 6}$ ratios), which favored a greater condensation of structures of aromatic organic compounds. Based on the obtained results it may be concluded with great probability that humic acids that were present in the compost without the addition of microbiological inoculum (C4) had a lower molecular weight.

\section{Conclusions}

1. Polymer material added to the composted biomass did not cause considerable changes in the content of humic compounds in the composts. The differences were observed in the share of soluble humic compounds in the total carbon in composts.

2. The composts with the addition of polymer materials had a greater share of non-hydrolyzing carbon in total carbon content $(71.6-77.3 \%)$ than the control compost $(69.5 \%)$.

3. Based on the value of the Cha:Cfa ratio and optical parameters of humic acids, a generally slowing down effect of adding polymer materials on mineralization and humification of the composted biomass was registered.

\section{Abbreviations}

$\mathrm{A}_{2 / 4}$ - ratio of absorbance values at wavelengths of 280 and $465 \mathrm{~nm}$

$\mathrm{A}_{2 / 6}$ - ratio of absorbance values at wavelengths of 280 and $665 \mathrm{~nm}$

$\mathrm{A}_{4 / 6}$ - ratio of absorbance values at wavelengths of 465 and $665 \mathrm{~nm}$

$\mathrm{Ct}-\quad$ content of total carbon, $\mathrm{g} \cdot \mathrm{kg}^{-1} \mathrm{~d} . \mathrm{m}$.

Cex - content of extracted carbon, $\mathrm{g} \cdot \mathrm{kg}^{-1}$ d.m.

Cha - content of carbon of humic acids, $g \cdot \mathrm{kg}^{-1} \mathrm{~d} . \mathrm{m}$.

$\mathrm{Cfa}-$ content of carbon of fulvic acids, $\mathrm{g} \cdot \mathrm{kg}^{-1} \mathrm{~d} . \mathrm{m}$.

Chem - content of carbon of hemicelluloses, $g \cdot \mathrm{kg}^{-1} \mathrm{~d} . \mathrm{m}$.

$\mathrm{Cnh}-$ content of non-hydrolyzing carbon, $\mathrm{g} \cdot \mathrm{kg}^{-1} \mathrm{~d} . \mathrm{m}$.

$\mathrm{Nt}-$ content of total nitrogen, $\mathrm{g} \cdot \mathrm{kg}^{-1} \mathrm{~d} . \mathrm{m}$.

\section{Acknowledgements}

This work was carried out within the framework of the POIG 01.01.02-10-123/09 project, "Utilization of biomass for the preparation of environmentally friendly polymer materials" (project coordinator: Lodz University of Technology, time of realization: 2010-14). 


\section{References}

1. MISHRA D.R., NAYAK N.C., MOHANTY P., NAYAK P.L. Phisico-chemical properties of environmental friendly starch-MMT nanocomposites for filmmaking. Int. J. Plant, Anim. Environ. Sci. 1, 134, 2011

2. SIRACUSA V., ROCCULI P., ROMANI S., ROSA M.D. Biodegradable polymers for food packaging. A review. Trends Food Sci. Technol. 19, (12), 634, 2008

3. LAU A.K., CHEUK W.W., LO K.V. Degradation of greenhouse twines derived from natural fibers and biodegradable polymer during composting. J. Environ. Manage. 90, (1), 668, 2009.

4. SHAH A.A., HASAN F., HAMEED A., AHMED S. Biological degradation of plastic. A comprehensive review. Biotechnol. Adv. 26, (3), 246, 2008.

5. WEBB H.K., ARNOTT J., CRAWFORD R.J., IVANOVA E.P. Plastic degradation and its environmental implications with special reference to poly(ethylene terephthalate). Polymers 5, 1, 2012.

6. MOONEY B.P. The second green revolution? Production of plant-based biodegradable plastics. Biochem. J. 418, 219, 2009.

7. LEJA K., LEWANDOWICZ G. Polymer biodegradation and biodegradable polymers - a review. Pol. J. Environ. Stud., 19, (2), 255, 2010.

8. GOUDA M.K., SWELLAM A.E., OMAR S.H. Biodegradation of synthetic polyesters (BTA and PCL) with natural flora in soil burial and pure cultures under ambient temperature. Res. J. Environ. Earth Sci. 4, (3), 325, 2012

9. OSANAI Y., TOSHIMA K., MATSUMURA S. Transformation of biodegradable polyesters into cyclic oligomers under continuous flow using an enzyme-packed column. Macromol. Biosci. 20, (4), 936, 2004.

10. RUTKOWSKA M., HEIMOWSKA A., KRASOWSKA K., JANIK H. Biodegradability of polyethylene starch blends in sea water. Pol. J. Environ. Stud. 11, (3), 267, 2002.

11. IOVINO R., ZULLO R., RAO M.A., CASSAR L., GIANFREDA L. Biodegradation of poly(lactic acid)/starch/coir biocomposites under controlled composting conditions. Polym. Degrad. Stab. 93, (1), 147, 2008

12. DAVIS G., SONG J.H. Biodegradable packaging based on raw materials from crops and their impact on waste management. Ind. Crops Prod. 23, (2), 147, 2006.

13. PIKOŃ K., CZOP M. Environmental impact of biodegradable packaging waste utilization. Pol. J. Environ. Stud. 23, (3), 969, 2014

14. CZAJA-JAGIELSKA N., MELSKI K. Biodegradation of starch-based films in conditions of nonindustrial composting. Pol. J. Environ. Stud. 22, (4), 1039, 2013.

15. KO H.J., KIM K.Y., KIM H.T., KIM CH.N., UMEDA M. Evaluation of maturity parameters and heavy metal contents in composts made from animal manure. Waste Manage. 28, 813,2008

16. NEKLYUDOV A.D., FEDOTOV G.N., IVANKIN A.N. Intensification of composting processes by microorganisms. Appl. Biochem. Microbiol. 44, (1), 6, 2008.

17. MIKOŁAJSKA A., RAJKIEWICZ M., ŚWIERZMOTYSIA B. Biodegradable materials containing thermoplastic starch. Elastomery 11, (1), 3, 2007.
18. GLEADALL A., PAN J., KRUFT M. A., KELLOMÄKI M. Degradation mechanisms of bioresorbable polyesters. Part 2. Effects of initial molecular weight and residual monomer. Acta Biomater. 10, 2233, 2014.

19. KRASOWSKA K., HEJMOWSKA A., RUTKOWSKA M. Enzymatic and hydrolytic degradation of poly(e-caprolactone) in natural environment. Polimery 51, (1), 21, 2006.

20. TSUJI H., MIYAUCHI S. Enzymatic hydrolysis of poly(lactide)s: effects of molecular weight, L-lactide content, and enantiomeric and diastereoisomeric polymer blending. Biomacromolecules 2, (2), 597, 2001.

21. GRIFFITH S.M., SCHNITZER M. A study in the infrared of high-molecular weight organic matter extracted by various reagents from a podzolic B horizon. Soil Sci. Soc. Am. Proc. 39, 861, 1975.

22. GONET S.S., DĘBSKA B., ZAUJEC A., BANACH-SZOTT M. Properties of humus of natural forest soil and arable soil. Ekologia (Bratislava, Slovakia) 27, (4), 351, 2008.

23. IGLESIAS JIMÉNEZ E., PÉREZ GARCIA V. Determination of maturity indices for city refuse composts. Agric., Ecosyst. Environ. 38, 331, 1992.

24. MOHAN S.K., SRIVASTAVA T. Microbial deterioration and degradation of polymeric materials. J. Biochem. Tech. 2, (4), 210, 2010.

25. KOPEĆ M., GONDEK K., BARAN A. Assessment of respiration activity and ecotoxicity of composts containing biopolymers. Ecotoxicol. Environ. Safe. 89, 137, 2013.

26. TUOMELA M., VIKMAN M., HATAKKA A., ITÄVAARA M. Biodegradation of lignin in a compost environment: a review. Bioresource Technol. 72, 169, 2000.

27. PAN I., SEN S.K. Microbial and physico-chemical analysis of composting process of wheat straw. Indian J. Biotechnol. 12, 120, 2013.

28. RAJ D., ANTIL R.S. Evaluation of maturity and stability parameters of composts prepared from agro-industrial wastes. Bioresource Technol., 102, (3), 2868, 2011.

29. GONDEK K., KOPEĆ M. Content of selected macro and microelements in composted biodegradable municipal waste. Acta Agroph. 19, (3), 527, 2012 [In Polish].

30. PARE T., DINEL H., SCHNITZER M., DUMONTET S. Transformations of carbon and nitrogen during composting animal manure and shredded paper. Biol. Fert. Soils 26, (3), $173,1998$.

31. GU J-D. Microbiological deterioration and degradation of synthetic polymeric materials. Int. Biodeter. Biodegr. 52, (2), 69, 2003

32. INBAR Y., CHEN Y., HADAR Y. Humic substances formed during the composting of organic matter. Soil Sci. Soc. Am. J. 54, (5), 1316, 1990.

33. GUSIATIN Z.M., KULIKOWSKA D. Transformations of humic substances, nitrogen and heavy metal forms in sewage sludge composted in a mixture with lignocellulosic waste. Inż. Ekol. 28, 82, 2012 [In Polish].

34. DĘBSKA B. Properties of humic substances of soil fertilized with slurry. Wydawnictwo Uczelniane ATR, Bydgoszcz 2004 [In Polish].

35. KALEMBASA D., BECHER M., BIK B., MAKOLEWSKI A. Organic matter properties of spent mushroom substrate. Acta Agrophys., 19, (4), 713, 2012 [In Polish].

36. INBAR Y., CHEN Y., HADAR Y. Solid-state carbon-13 nuclear magnetic resonance and infrared spectroscopy of composted organic matter. Soil Sci. Am. J. 53, (6), 1695, 1989. 
